\title{
Consumer evaluation of perceived risks for goods and services
}

\author{
Mike Bendixen \& Graham Gault \\ Graduate School of Business Administration, University of the Witwatersrand. P.O. Box 98, Wits, 2050 Republic of South Africa
}

\author{
Received May 1995
}

\begin{abstract}
Perceived risk is known to be an important determinant of consumer behaviour. However, prior research has focussed on goods rather than services. The purpose of this exploratory research was to identify any differences between goods and services in terms of perceived risk and risk reduction strategies. Two new components of risk, namely specification risk and the risk of loss of control, were identified as being specifically associated with services. Empirical evidence gathered leads to the conclusion that as far as risk is concerned, a simple classification of products as goods or services is inadequate: an additional hybrid class comprising both goods and services is also necessary. These three categories of product are associated with different types of perceived ask. Also, risk reduction strategies were found to be dependent on product rather than on the type of risk.
\end{abstract}

\begin{abstract}
Waarneembare risiko word as 'n belangrik determinant van verbruikersgedrag beskou. Die fokus het egter in vroeëre navorsing in 'n groter mate op goedere as dienste geval. Die doel van hierdie ondersoekende navorsing was om enige verskille tussen goedere en dienste te identifiseer ten opsigte van waameembare risiko en risikoverminderingstrategieè. Twee nuwe komponente van risiko, naamlik spesifikasierisiko en die risiko van verlies aan beheer, is geïdentifiseer as risiko's wat in die besonder met dienste geassosieer word. Die empiriese bewyse wat ingesamel is, lei daartoe dat die gevolgtrckking gemaak word dat sover as wat dit risiko aangaan, 'n eenvoudige klassifikasie van produkte as goedere of dienste onvoldoende is: ' $n$ adddisionele basterklas wat uit beide goedere en dienste bestaan, is ook noodsaaklik. Hierdie drie kategorieë van produkte word met verskillende tipes waarneembare risiko geassosieer. Daar is ook gevind dat risikoverminderingstrategieë afhanklik is van die produk, eerder as die tipe risiko.
\end{abstract}

\section{Introduction}

It has long been recognized that perceived risk plays an important role in consumer buyer behaviour (for instance Bauer, 1967; Cox, 1960; Taylor, 1974; Engel, Blackwell \& Miniard, 1986). Cox states:

'The basic assumption is that consumer behaviour is goal orientated. When the consumer identifies a situation and defines a set of buying goals with uncertainty being perceived in changing from the existing state to attain the goals, then risk is said to exist' (1967: 37).

The study of perceived risk has been primarily focussed on consumer buying behaviour with respect to goods (for instance, Cunningham, 1967; Perry, \& Hamm, 1969; Jacoby \& Kaplan, 1972; Kaplan, Szybillo \& Jacoby, 1974; Lutz \& Reilly, 1973 and Bettman, 1973). The literature relating to perceived risk for services is limited (for instance Lewis, 1976; Guseman, 1977; 1981 and George, Weinberger \& Kelly, 1985). More recent research exploring the evaluation process of goods and services (for instance Ewels, 1989; Venegas, 1990; Kellen, 1990; Anderson, 1991; Cambitzi, 1991 and Borman, 1993) has indicated that different aspects of perceived risk are key discriminators between goods, services and knowledge products.

The purpose of this exploratory research was to identify any differences between goods and services in terms of perceived risk and risk reduction strategies.

\section{Literature review}

Roselius (1971) found empirical evidence that consumers have preferences for different methods of risk reduction for different types of loss or risk. He identified time, hazard, ego and money as the primary types of losses that consumers can incur. In the Jacoby \& Kaplan (1972) study, five components of risk were identified, namely performance, social, financial, physical and psychological risk plus a measure of global (overall) risk. Performance risk was found to explain more than any other type of consequence across twelve different goods. Lewis (1976), using these six measures plus the time risk dimension suggested by Roselius (1971), studied ten services, ten goods and ten good-service combinations. He found that services were perceived to be riskier than goods in all types of risk except physical, where there were no perceived differences. Good-service combinations were perceived to represent higher risk than goods on all dimensions of risk.

Cunningham (1967) conceptualized perceived risk as comprising the components of uncertainty and consequence. He used these two scales to derive a global perceived risk measure. Guseman (1977) utilized the Cunningham (1967) approach of looking at uncertainty and consequences to examine the differences between goods and services. He also made use of the components of physical, financial, ego and time loss. Guseman (1977) found that services were perceived as having more risk than goods on all dimensions.

George, Weinberger \& Kelly (1985), using an instrument very similar to that of Lewis (1976), studied four paired goods-services (for example colour television and colour television repair) which were evaluated by 100 consumers in a mall intercept study. Important differences between product pairs were found; for instance, the good was found to be more risky on the financial dimension for the colour television/colour television repair pair while the service was found to be more risky for the eyeglasses/eye examination and carpeting/ carpet cleaning pairs. These findings led George et al. to conclude:

'As contrasted with the previous work by Lewis (1976) and Guseman $(1977 ; 1981)$, an important finding of this study is that the generalizations suggesting that services are universally perceived as more risky than goods are extremely tenuous?' (1985: 91).

Zeithaml posited eleven hypotheses regarding the differences in the consumer evaluation processes between goods 
and services. Besides the generic hypothesis that consumers perceive greater risks when buying services (hypothesis 8 ), she states:

'Hypothesis 10: Consumers attribute some of their dissatisfaction with services to their own inability to specify or perform their part of the service.

Hypothesis 11: Consumers may complain less frequently about services than about (goods) due to their belief that they themselves are partly responsible for their dissatisfaction' (1981: 189).

Both of these hypotheses encapsulate a category of risk not previously identified in the literature, namely specification risk which is the risk of the consumer having difficulty in specifying the nature of the desired service. Ewels (1989) tested the Zeithaml (1981) hypotheses and confirmed that risk was indeed the principal discriminator between certain categories of goods and services. Durable goods as well as equipment-based, customized services with a low degree of customer involvement (for example television repair, car repair or service, household move) were characterized by the locus of risk being in the product itself. In contrast, customized services with a high degree of consumer involvement (for example legal advice, medical diagnosis, restaurant meal) and standardized services and convenience goods (for example toothpaste, fruit juice, dry cleaning, photographic developing) were characterized by the locus of risk in the specification of the product.

Venegas (1990) replicated this study for office supply products, Kellen (1990) for hospital in-patient services and Anderson (1991) for computer goods, services and strategic software. In all cases, locus of risk emerged as a key discriminator among the products studied and the importance of specification risk was confirmed. Cambitzi (1991) replicated and extended the Ewels (1989) study by incorporating additional hypotheses that discriminate between goods and services based on consumer behaviour theory and qualitative research input. As far as risk was concerned, these studies confirmed Ewels' (1989) findings.

Bendixen (1991) consolidated these results to develop the consumer evaluation model illustrated in Figure 1. The pure goods segment is characterized by products having high degrees of search qualities and hedonistic utility. The evaluation process includes the use of price, brand name and store name as indicators of quality. Specification and ego risk are also characteristic of this segment. Typical products include durable and semi-durable products such as new car, furniture, television set, car tyres, suitcase, clothing.

The grudge purchase segment is characterized by functional utility and a high level of search qualities as well as a high degree of conventional (performance and physical) risk.

Typical products include a used car, household move, television repair and car service. The pure service segment is characterized by high degrees of credence qualities and functional utility. The evaluation process encompasses the appearance of premises and staff as well as the presence of other consumers as indicators of quality. There is a reluctance by the consumer to change supplier or try anything new as well as a feeling of little choice of alternative suppliers. Word of mouth recommendation is key to decision-making. Typical products include legal advice, medical diagnosis, nursery

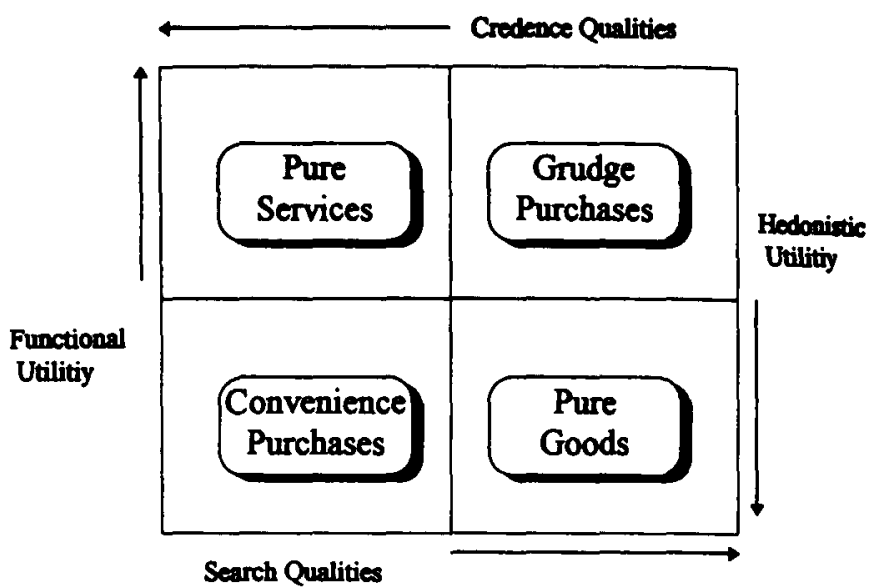

Figure 1 Consumer evaluation model

school care, banking and life insurance. The convenience purchase segment is characterized by high degrees of credence qualities and hedonistic utility. Convenience, consideration of 'doing it yourself' and post-purchase evaluation are important aspects of the consumer evaluation process. Typical products include a mixture of goods and services such as toothpaste, fruit juice, dry cleaning and photographic development and printing.

Based on the research cited, the following propositions are posited:

- Proposition 1: Financial, ego, performance, pschological/ emotional, physical danger, time, specification and loss of control are distinct elements of perceived risk.

- Proposition 2: Different categories of products are characterized by different types of risk. A simple categorization of products as goods or services is insufficient in this regard.

Roselius (1971) identified eleven risk reduction methods used by consumers:

- endorsements;

- brand loyalty;

- major brand image;

- free sampling;

- store image;

- shopping around;

- word of mouth;

- money back guarantee;

- expensive model;

- private testing; and

- government testing.

Guseman (1981) adopted the risk reduction techniques developed by Roselius (1971) with a view to test the hypothesis that different risk relievers are used by consumers for goods rather than for services. He found that when purchasing services, consumers were more likely to use the most conveniently located store and use reference groups for goods. Consumers were also less likely to seek information from the store and shop around when purchasing services. 
Based on these findings, the following additional proposition is posited:

- Proposition 3: Consumers use different risk reduction techniques when buying goods than when buying services.

\section{Research methodology}

In order to test these three propositions, a two-staged study was conducted. In the first stage, in-depth interviews were conducted with a quota sample of 15 female and 15 male adults. The Kelly repertory grid technique (see Fransella \& Bannister, 1977) was applied to identify the types of risk perceived by consumers. Respondents were presented with a triad of products with which they were familiar and asked to select the one that was most different from the other two in terms of perceived risk on purchasing. The description of why this product was different and what the other two products had in common yielded the underlying constructs of perceived risk. This technique was supplemented by asking respondents to describe the worst outcome scenario when purchasing each product. Respondents were also asked to describe what they could do and what they believed the marketer of the product could do to avoid any such outcome. The list of products (goods and services) is presented in Table 1.

Analysis of the responses confirmed the following aspects of perceived risk, all of which are mentioned in the literature:

1. overall risk;

2. financial risk;

3. ego risk;

4. performance risk;

5. psychological risk;

6. physical danger;

7. risk of wasting time; and

8. specification risk.

In addition, the risk of 'loss of control' by the consumer was identified as another potential dimension of perceived risk (designated risk number 9). This type of risk was associated with the services of a haircut and a restaurant meal.

Table 1 Key to products

\begin{tabular}{llll}
\hline & Services & & Goods \\
\hline BA & Banking & CL & Clothing \\
CC & Credit card & CT & Car tyres \\
CS & Car service & FJ & Fruit juice \\
DC & Dry cleaning & FU & Furniture \\
HC & Haircut & NC & New car \\
HS & Hotel service & SC & Suitcase \\
HM & Household move & TP & Toothpaste \\
LA & Legal advice & TV & Television \\
LI & Life insur ance & UC & Used car \\
MD & Medical diagnosis & & \\
NS & Nursery school & & \\
PD & Photo developing & & \\
RM & Restaurant meal & & \\
TR & Television repair & & \\
\hline
\end{tabular}

The questions relating to risk reduction strategies were analysed with a view to extract underlying themes. The following constructs emerged from this analysis:

1. brand loyalty reduces risk;

2. supplier image/phyical cvidence reduces risk;

3. risk is reduced by recommendations from friends;

4. a demonstration or trial reduces risk;

5. communicating my needs helps to reduce risk;

6. encouragement from the supplier to communicate reduces risk;

7. if I do my homework my risk is reduced;

8. supplier providing information reduces risk, and

9. professionalism/supplier expertise reduces risk.

In addition, service quality was alluded to in several interviews. Thus, for the purposes of the second stage of the research, this list was supplemented with statements reflecting the five dimensions of service quality identified by Parasuraman, Zeithaml \& Berry (1986), namely tangibles, reliability, responsiveness, assurance and empathy. The statements used were as follows:

10. appearance and manner of staff reduce risk (tangibles);

11. appearance of the facilities reduces risk (tangibles);

12. dependability, accuracy and consistency reduce risk (reliability);

13. staff who provide prompt action reduce risk (responsiveness);

14. staff who convey trust and confidence reduce risk (assurance); and

15. caring, individualized attention reduces risk (empathy).

In the second stage of the study, personal interviews were conducted with a quota sample of 60 female and 60 male adults in the Johannesburg area. Each of the nine components of risk and fifteen risk reduction strategies identified in the first stage of the research were converted into statements, for example for loss of control risk, the following statement was used: 'When deciding to purchase the following. I feel concerned as I am not in control of the outcome'.

Respondents were asked which of the 23 products listed in Table 1 (or none of these products) they associated with each statement.

The matrices of frequencies of product associations with the risk statements and the risk reduction strategies were each subject to correspondence analysis (Greenacre, 1984) and chi-squared trees analysis (Greenacre, 1988).

Hoffman \& Franke (1986: 213) describe correspondence analysis as an exploratory data analysis technique that 'scales the rows and columns of a rectangular data matrix in corresponding units so that each can be displayed graphically in the same low-dimensional space'. Technically, the technique 'can be classified as a compositional technique because it relies upon the association, for purposes of perceptual mapping, between objects and some form of descriptive characteristics' (Hair, Anderson, Tatham \& Black, 1992: 340).

In chi-squared trees analysis, the same contingency table is explored for homogeneity between its rows (or columns). This is achieved by seeking which combination of two rows (or columns) of the original data matrix results in the smallest change in the total chi-squared statistic. A small change in this statistic implies a similarity in the profiles of the 
combined rows (or columns). This procedure is repeated until the matrix is reduced to a single row (or column). The joining procece is mapped on a dendogram and the joining distance taken as the change in overall chi-squared statistic resulting from the combination of the two rows (or columns). In this way, clusters of rows (or columns) with similar profiles can be ascertained. When used in conjunction with correspondence analysis, the association between clusters of rows (for example descriptive characteristics) and clusters of columns (for example objects) can be made.

These analyses are appropriate for the identification of and description of the nature of any associations between the products and the components of risk and the products and risk reduction strategies. The risk reduction strategies were superimposed as supplementary points in the risk component space to establish whether there was any association between these two variables.

\section{Results}

\section{Components of risk}

An initial correspondence analysis run on the frequency matrix of components of risk and products indicated that the risk of physical danger was strongly associated with 'none of these' products. This strong association is sensible in light of the products chosen. These items had principal co-ordinates of -1132 and -967 on the first axis with contributions of $48.1 \%$ and $53.7 \%$ respectively. These values suggest that these elements of the frequency matrix were outliers (Hoffman \& Franke, 1986) and were therefore suppressed in subsequent analyses. The results of a subsequent correspondence analysis run are presented in Table 2 .

The dendograms from the chi-squared trees analysis of this data are presented in Figures 2 and 3. At a 5\% level of significance, the dendogram of products indicates that there are four, possibly five, distinct groupings while the dendogram of the components of risk indicates four distinct risk groupings. The relative positioning of the risk components and products in the three axis correspondence analysis solution allows for the determination of which product grouping is associated with which risk component grouping.

The strongest grouping is for those products associated with ego risk, namely toothpaste, furniture, suitcase and clothing. These products may be purchased by consumers for both functional purposes as well as an overt display of the image that they wish to project. It is interesting that all of the products associated with ego risk are goods.

Products such as a used car, a household move or a credit card are associated by consumers with an overall and financial risk. Overall and financial risk are associated with a mixture of goods and services that typically involve, directly or indirectly, items of high value.

Products such as medical diagnosis, nursery school care, legal advice, haircut and life insurance are associated with psychological and specification risk - consumers are uncomfortable with the fact that they may not acquire what they want or need partly as a result of their own inability to specify their needs. This class of risk appears to be associated only with services requiring professional or specialized skills or knowledge.
Forcing a five group solution of the results of the correspondence and chi-squared trees analysis separates loss of control risk as being associated with photographic developing, dry cleaning, television repair and car service. It is interesting to note that this distinctive class of risk is associated with only equipment-based services.

The last grouping is the association of performance and time risk with products such as banking, new car, television, car tyres, hotel service, fruit juice and a restaurant meal. This group of products is also a mixture of goods and services that appear to be characterized by standardization and strong branding.

These results are summarized in Table 3. It is apparent that Proposition 1 is not supported by the empirical evidence gathered in this study as only five distinct components of risk are indicated. However, the results do support Proposition 2. While some of the product/risk groupings are distinctly goods or services, others are hybrids of these two broad categories of product.

\section{Risk reduction strategies}

The results of the correspondence and chi-squared trees analyses applied to the frequency matrix of risk reduction strategies and products are presented in Table 4 and Figures 4 and 5 respectively.

Both risk reduction strategy and product dendograms indicate the presence of five distinct clusters at a $5 \%$ level of significance. The relative positioning of the risk reduction strategies and products in the three axis correspondence analysis solution allows for the determination of which product grouping is associated with which risk reduction strategy grouping.

The most striking grouping is for the goods new car, used car and television for which demonstration and trial is perceived to be the appropriate risk reduction strategy. Another grouping is for consumer goods (toothpaste, fruit juice) where brand loyalty, supplier image and physical evidence are the associated risk reduction strategies.

Financial service products, such as banking, credit card and life insurance, group together. Consumers doing their homework from information provided by the supplier is seen to reduce risk for these services. A large group of services such as household move, nursery school, medical diagnosis, legal advice, haircut, hotel service and restaurant meal are grouped together. Recommendations from friends, tangibles (staff and facilities), responsiveness and caring, individual attention are perceived as reducing risk for this group.

Table 2a Output of correspondence analysis

\begin{tabular}{lccc}
\hline \multicolumn{4}{c}{ (a) Eigenvalue report } \\
\hline Axis & Eigenvalue & Individual \% & Cumulative \% \\
\hline 1 & 0.08878 & 41.94 & 41.94 \\
2 & 0.04720 & 22.30 & 64.24 \\
3 & 0.04442 & 20.99 & 8523 \\
4 & 0.01593 & 7.53 & 92.75 \\
5 & 0.00718 & 3.39 & 96.15 \\
6 & 0.00440 & 2.08 & 98.22 \\
7 & 0.00376 & 1.78 & 100.00 \\
Total & 0.21166 & - & - \\
\hline
\end{tabular}


Table 2b Detail report - products

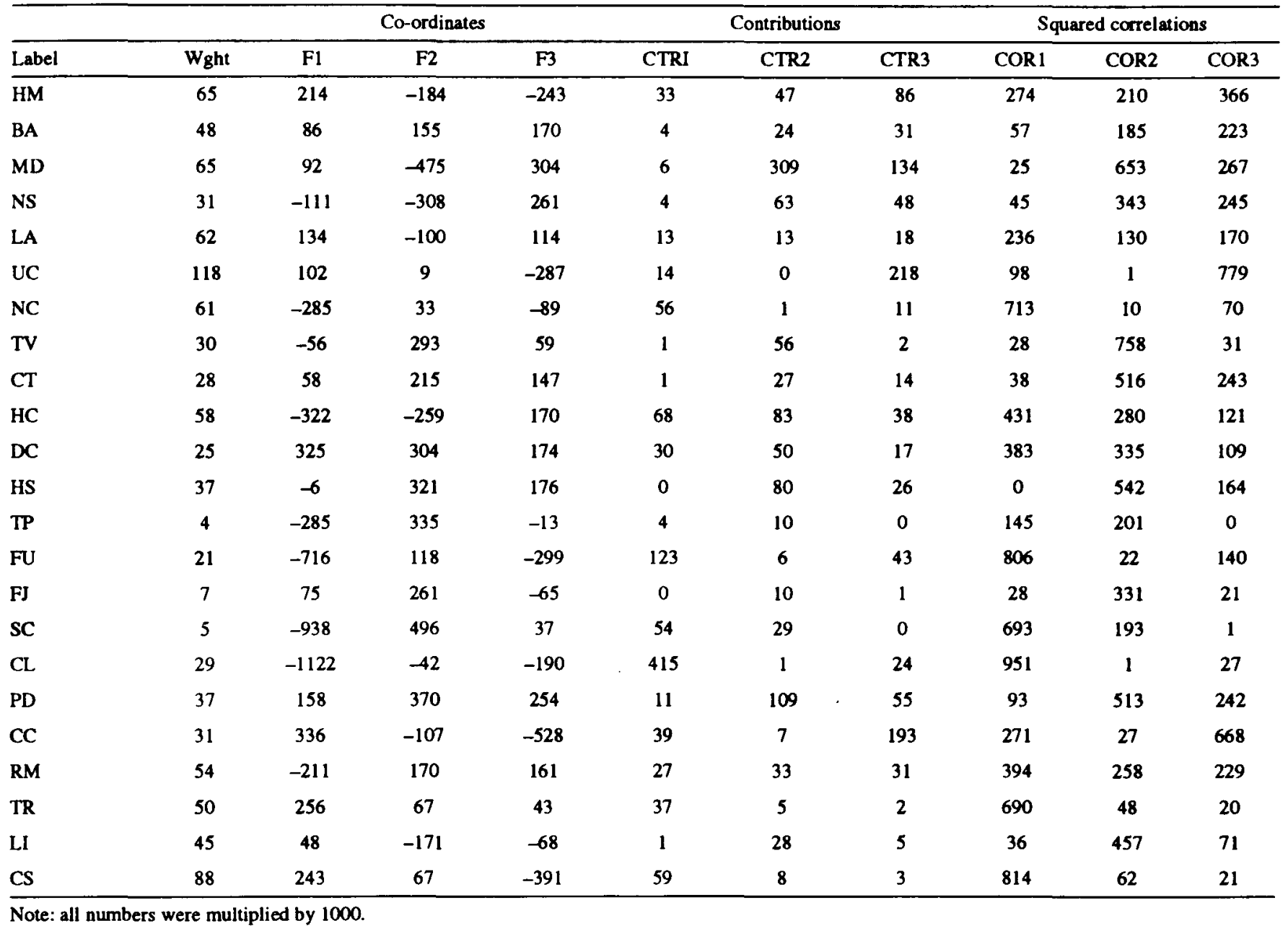

Note: all numbers were multiplied by 1000 .

(c) Detail report - risks

\begin{tabular}{lcccccccccc}
\hline & & \multicolumn{3}{c}{ Co-ordinates } & \multicolumn{3}{c}{ Contributions } & \multicolumn{3}{c}{ Squared correlations } \\
\hline Label & Wght & G1 & G2 & G3 & CTRI & CTR2 & CTR3 & COR1 & COR2 & COR3 \\
\hline Overall & 140 & 224 & -54 & -199 & 79 & 9 & 124 & 341 & 20 & 268 \\
Financial & 128 & 257 & -67 & -376 & 95 & 12 & 408 & 273 & 18 & 584 \\
Ego & 108 & -792 & 12 & -186 & 767 & 0 & 85 & 944 & 0 & 52 \\
Performance & 203 & -16 & 270 & 96 & 1 & 313 & 42 & 3 & 740 & 94 \\
Psychological & 96 & -26 & -435 & 169 & 1 & 384 & 62 & 3 & 767 & 116 \\
Time & 63 & 121 & 244 & 159 & 15 & 140 & 64 & 90 & 366 & 156 \\
Specification & 151 & -104 & -323 & 308 & 8 & 139 & 134 & 42 & 399 & 363 \\
Loss of control & 30 & 136 & -34 & 155 & 32 & 4 & 82 & 281 & 17 & 365 \\
\hline Note: all numbers were multiplied by 1000. & & & & & & & & &
\end{tabular}

A mixed group of durable or semi-durable goods (furniture, car tyres, suitcase and clothing) and equipment-based services (dry cleaning, photographic developing, television repair and car service) are grouped together. Communication by the consumer, encouragement to do so by the supplier, supplier expertise and dependability are the associated risk reduction strategies for this group. This gamut of strategies all appear to be aimed at substituting for demonstration or trial which is not easily achieved for this group of products.

The results relating to risk reduction strategies are summarized in Table 5 from which it is clear that a simple categorization of products into goods and service is insufficient to identify appropriate risk reduction strategies. This is a clear contradiction of Proposition 3.

The data collected for the components of risk and the risk reduction strategies have the products in common. Thus, correspondence analysis can be used to examine if there is any association between the type of risk and risk reduction strategy by using the one set of variables as supplementary to the other (Hoffmann \& Franke, 1986). When this analysis was performed, the positioning of risk reduction strategies in risk space (or vice versa) was rendered meaningless by the very low quality of representation of the supplementary variables (typically $20 \%$ or less). This implies that risk reduction strategies are product specific and not risk specific. 


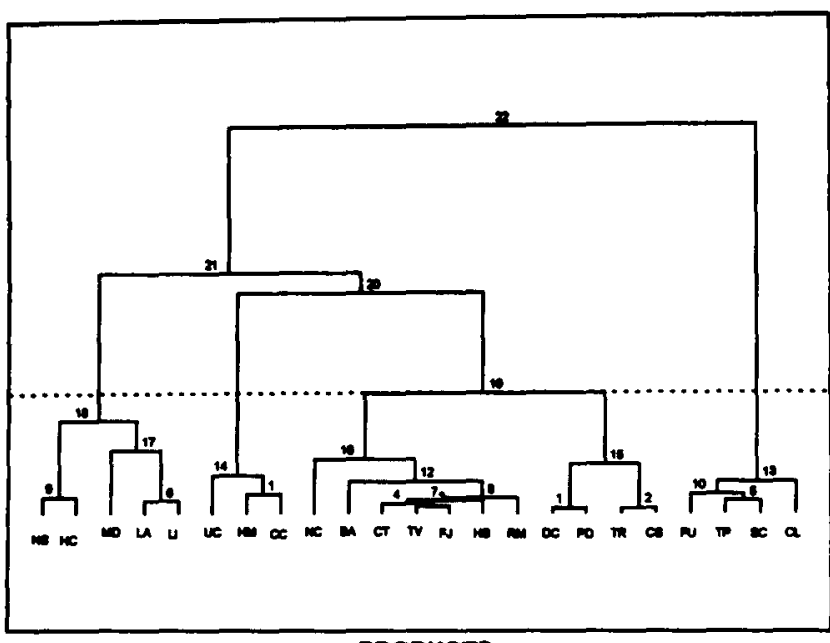

PRODUCTS

Figure 2 Dendogram for 'products' resulting from the $\chi^{2}$ trees analysis of the components of risk matrix

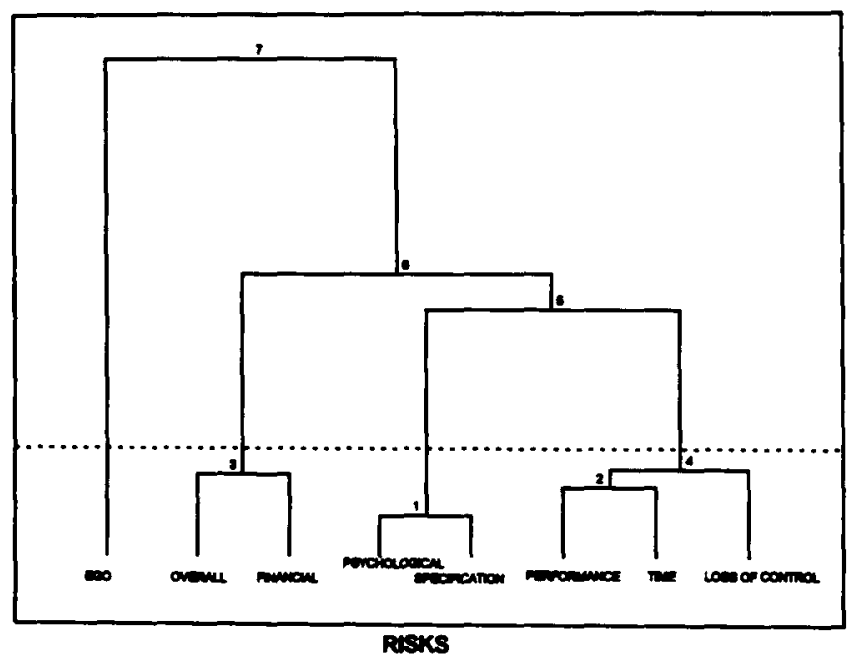

Figure 3 Dendogram for 'risks' resulting from the $\chi^{2}$ trees analysis of the components of risk matrix

Table 3 Product/risk groupings

\begin{tabular}{lll}
\hline & Characteristic risk & Characteristic products \\
\hline 1 & Ego & Image enhancing goods \\
2 & Overall and financial & $\begin{array}{l}\text { Goods or services having a high } \\
\text { value }\end{array}$ \\
3 & Psychologicalemotional and & Services demanding professional $\alpha$ \\
& specification & specialized skills or knowledge \\
5 & Loss of control & Equipment-based senvices \\
5 & Performance and time & Standardized goods or services
\end{tabular}

\section{Conclusions}

\section{Implications for management}

The findings of this study have some important implications for managment. Firstly, two new components of risk have been uncovered, namely specification risk and the risk of loss of control.

Specification risk is associated with those services demanding professional or specialized skills or knowledge (such as medical diagnosis, legal advice, life insurance, nursery school care and a haircut). An understanding that buyers of this cate-

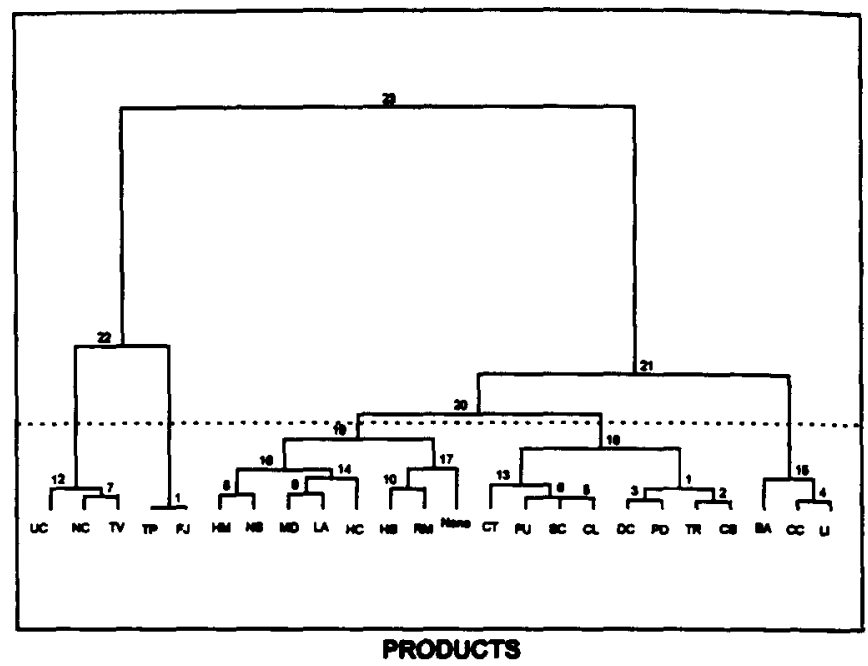

Figure 4 Dendogram for 'products' resulting from the $\chi^{2}$ trees analysis of the risk reduction strategies matrix

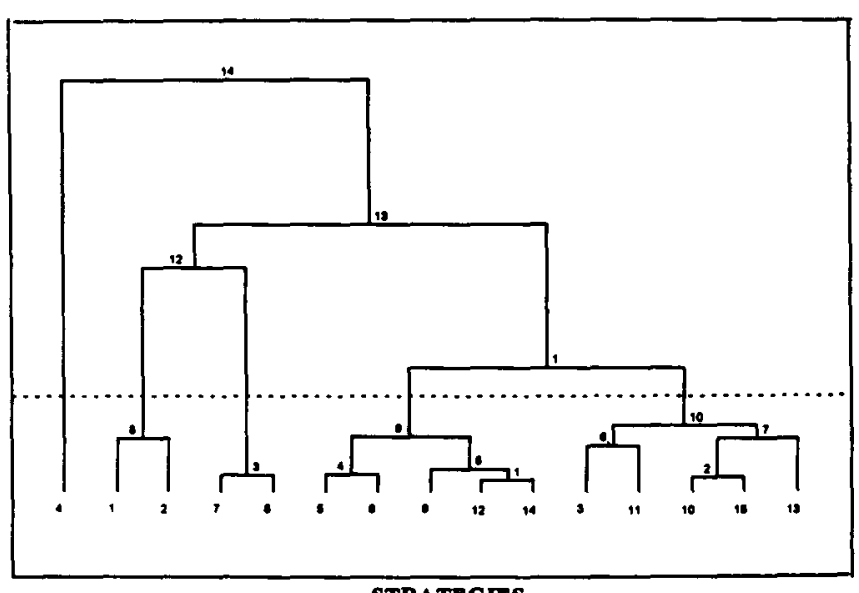

STRATEGES

Figure 5 Dendogram for 'strategies' resulting from the $\chi^{2}$ trees analysis of the risk reduction strategies matrix

Table 4a Output of correspondence analysis

\begin{tabular}{|c|c|c|c|}
\hline \multicolumn{4}{|c|}{ (a) Eigenvalue report } \\
\hline Axis & Eigenvalue & Individual \% & Cumulative $\%$ \\
\hline 1 & 0.04022 & 39.31 & 39.31 \\
\hline 2 & 0.01953 & 19.09 & 58.40 \\
\hline 3 & 0.01757 & 17.17 & 75.57 \\
\hline 4 & 0.00659 & 6.44 & 82.01 \\
\hline 5 & 0.00634 & 6.20 & 88.21 \\
\hline 6 & 0.00366 & 3.58 & 91.79 \\
\hline 7 & 0.00307 & 3.00 & 94.79 \\
\hline 8 & 0.00186 & 1.82 & 96.61 \\
\hline 9 & 0.00108 & 1.05 & 97.66 \\
\hline 10 & 0.00088 & 0.86 & 98.53 \\
\hline 11 & 0.00066 & 0.64 & 99.17 \\
\hline 12 & 0.00042 & 0.41 & 99.58 \\
\hline 13 & 0.00026 & 0.25 & 99.84 \\
\hline 14 & 0.00376 & 0.16 & 100.00 \\
\hline Toxal & 0.10232 & - & - \\
\hline
\end{tabular}

gory of services have difficulty in identifying what it is that they want or need, points to the need for an emphasis being 
Table 4b Detail report - products

\begin{tabular}{|c|c|c|c|c|c|c|c|c|c|c|}
\hline \multirow[b]{2}{*}{ Label } & \multirow[b]{2}{*}{ Wght } & \multicolumn{3}{|c|}{ Co-ordinates } & \multicolumn{3}{|c|}{ Contributions } & \multicolumn{3}{|c|}{ Squared correlations } \\
\hline & & Fl & $\mathbf{F} 2$ & F3 & CTR1 & CTR2 & CTR3 & CORI & COR2 & $\mathrm{COR3}$ \\
\hline$\overline{\mathrm{HM}}$ & 49 & -58 & 83 & 51 & 4 & 17 & 7 & 83 & 168 & 65 \\
\hline BA & 64 & -156 & 114 & 110 & 39 & 43 & 44 & 318 & 171 & 157 \\
\hline MD & 56 & -215 & -11 & -55 & 64 & 0 & 10 & 641 & 2 & 42 \\
\hline NS & 48 & -117 & 36 & -70 & 16 & 3 & 13 & 356 & 33 & 127 \\
\hline LA & 56 & -171 & 89 & 46 & 40 & 23 & 7 & 567 & 155 & 41 \\
\hline UC & 68 & 351 & 107 & -209 & 207 & 39 & 167 & 669 & 62 & 236 \\
\hline $\mathrm{NC}$ & 64 & 333 & 137 & -73 & 176 & 61 & 19 & 789 & 133 & 38 \\
\hline TV & 46 & 386 & -3 & -10 & 172 & 0 & 0 & 963 & 0 & 1 \\
\hline CT & 38 & 110 & -18 & 182 & 11 & 1 & 71 & 198 & 5 & 540 \\
\hline $\mathrm{HC}$ & 43 & -209 & -59 & 76 & 46 & 7 & 14 & 359 & 28 & 48 \\
\hline DC & 26 & -105 & -163 & -19 & 7 & 36 & 1 & 149 & 361 & 5 \\
\hline HS & 51 & -228 & -82 & -135 & 65 & 17 & 53 & 474 & 62 & 168 \\
\hline TP & 16 & 364 & -484 & 333 & 52 & 191 & 101 & 273 & 485 & 230 \\
\hline $\mathrm{FU}$ & 33 & 84 & -87 & 29 & 6 & 13 & 2 & 192 & 206 & 24 \\
\hline FJ & 15 & 315 & -461 & 314 & 38 & 168 & 87 & 232 & 496 & 231 \\
\hline SC & 15 & 22 & -136 & 167 & 0 & 15 & 24 & 4 & 159 & 239 \\
\hline $\mathrm{CL}$ & 29 & -9 & -167 & 88 & 0 & 42 & 13 & 1 & 392 & 109 \\
\hline PD & 29 & 45 & -127 & -22 & 1 & 24 & 1 & 26 & 213 & 6 \\
\hline $\mathrm{CC}$ & 31 & -12 & 259 & 231 & 0 & 106 & 94 & 1 & 495 & 396 \\
\hline $\mathbf{R M}$ & 54 & -170 & -139 & -154 & 38 & 53 & 72 & 323 & 215 & 265 \\
\hline TR & 41 & -45 & -31 & 4 & 2 & 2 & 0 & 58 & 27 & 1 \\
\hline LI & 59 & -72 & 202 & 186 & 8 & 122 & 115 & 61 & 475 & 402 \\
\hline $\mathrm{CS}$ & 60 & -57 & -52 & -83 & 5 & 8 & 23 & 107 & 90 & 226 \\
\hline None & 10 & 31 & -122 & -320 & 0 & 8 & 61 & 2 & 36 & 251 \\
\hline
\end{tabular}

Note: all numbers were multiplied by 1000 .

(c) Detail report - risks

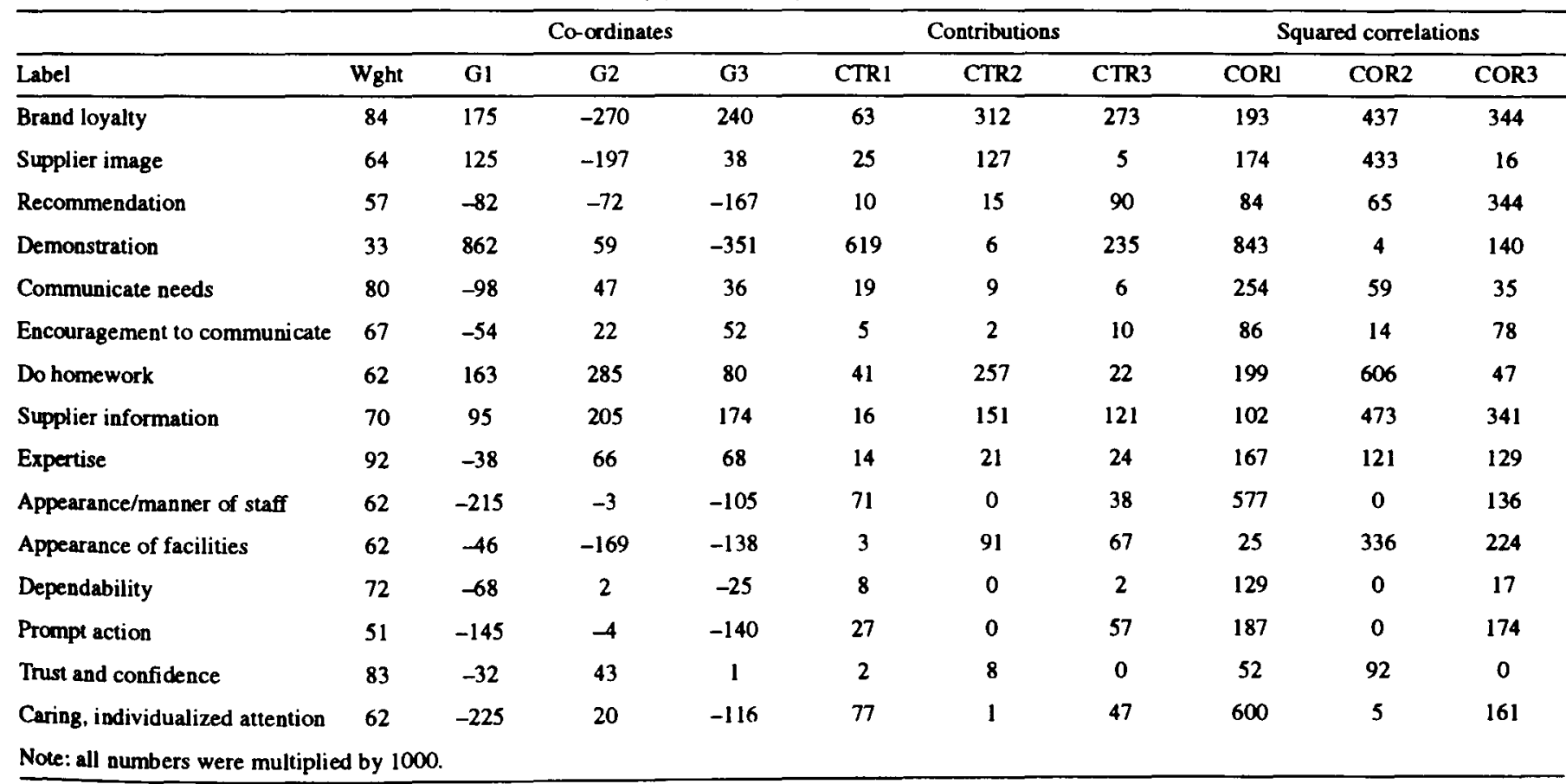

placed on the interaction process with the customer. This is consistent with the relationship marketing paradigm put forward by Grönroos $(1991 ; 1994)$.
The risk of loss of control is associated with equipmentbased services (such as a car service, television repair, dry cleaning and photographic developing). An understanding 
Table 5 Product/risk reduction strategy groupings

\begin{tabular}{|c|c|c|}
\hline & Characteristic strategy & Characteristic products \\
\hline 1 & Trial or demonstration & Durable goods \\
\hline 2 & Brand image & Consumer goods \\
\hline 3 & Information search & Financial services \\
\hline 4 & $\begin{array}{l}\text { Tangible evidence, responsiveness } \\
\text { and recommendation }\end{array}$ & General services \\
\hline 5 & Communication and expertise & $\begin{array}{l}\text { Goods and equipment-based services } \\
\text { where demonstration is possible }\end{array}$ \\
\hline
\end{tabular}

that buyers of this category of services need reassurance that the necessary technological expertise is available again points to the need for an emphasis on the customer interaction process and relationship marketing. While loss of control has not previously been identified as a specific class of risk, Armistead (1989) identifies that 'feelings of being in control' are part of the 'steering' dimension of customer service. This link between perceived risk and customer service implies that the successful management of this risk is likely to be directly reflected in customers' perceptions of the quality of service provided.

This study provides further empirical evidence that a simple classification of products in terms of goods and services is inadequate. In terms of risk and risk reduction strategies, there are classes of goods, classes of services and hybrid classes of goods and services. Also, risk reduction strategies tend to be product specific and not risk specific. Management should thus be wary of following generic marketing strategies that are based on either the simple categorization of products into goods or services, or, generic risk reduction strategies based on type of risk.

\section{Implications for future research}

From the summarized results presented in Table 5 , it is interesting to note that the risk reduction strategies of trial/ demonstration, brand image, the provision of tangible evidence, information search and the communication of expertise are readily addressed by the promotional element of the marketing $\mathrm{mix}$ (Borden, 1964). However, being responsive to customers and relying on the recommendations of others require marketing efforts that are not readily incorporated into the traditional elements of the marketing mix. Relationship marketing (Grönroos, 1991; 1994) represents a more meaningful approach to the development of these types of risk reduction strategies as well as the management of specification and loss of control risks. This indicates the need for the development or updating of the $4 \mathrm{P}$ marketing framework (usually attributed to McCarthy, 1960) into a richer paradigm that specifically recognizes services and hybrid products.

Although this exploratory study was conducted using a limited set of products and using relatively small and geographically restricted samples, some useful insights have resulted. Future research could confirm these findings for different product sets using larger samples based on a wider geographical base.

\section{References}

Anderson, F.C. 1991. Strategic computer software: determinants of quality. Unpublished MBA research report, Johannesburg: University of the Witwatersrand.

Armistead, C.G. 1989. 'Customer service and operations management in service businesses', The Service Industries Journal, Vol. 9, No. 2: 247-259.

Bauer, R.A. 1960. 'Consumer behaviour as risk taking' . In Hancock, R. S. (ed.). Dynamic Marketing for a Changing World. Chicago: American Marketing Association, p23-33pp.

Bendixen, M.T. 1991. The evaluation process of goods and services. Paper presented at the Second National Marketing Educators' Conference, Stellenbosch: University of Steffenbosch, November.

Bettman, J.R. 1973. 'Perceived risk and its components: a model and empirical test', Journal of Marketing Research, Vol. 10, May: 184-190.

Borden, N.H. 1964. 'The concept of the marketing mix', Journal of Advertising Research, Vol. 4, June: 2-7.

Borman, A.E. 1993. Beyond goods and services: product classification in the 'information age'. Unpublished MBA research report, Johannesburg: University of the Witwatersrand.

Cambitzi, C. 1991. Evaluation of goods and services among white and black consumers. Unpublished MBA, research report, Johannesburg: University of the Witwatersrand.

Cox, D.F. 1967. 'Risk handling in consumer behaviour'. In Cox, D.F. (ed.). Risk taking and information handling in consumer be haviour. Boston: Graduate School of Business Administration, Harvard University, 34-81pp.

Cunningham, S.M. 1967. 'The major dimensions of perceived risk' In Cox, D.F. (ed.). Risk taking and information handling in consumer behaviour. Boston: Graduate School of Business Administration, Harvard University, 82-108pp.

Engel, J.F., Blackwell, R.D. \& Miniard, P.W. 1986. Consumer behaviour. Sth edition, Chicago: The Dryden Press.

Ewels, C.N. 1989. Consumer evaluation of goods and services. Unpublished MBA research report, Johannesburg: University of the Witwatersrand.

Fransella, F. \& Bannister, D. 1977. A manual for repertory grid techniques. London: Academic Press Inc.

George, W.R., Weinberger, M.G. \& Kelly, J.P. 1985. 'Consumer risk perceptions: managerial tool for the service encounter'. In Czepiel, J.A., Solomon, M.R. \& Surprenant, C.F. (eds.). The service encounter: managing employeer/customer interaction in service businesses. Lexington: Lexington Books, 83-100pp.

Greenacre, M.J. 1984. Theory and applications of correspondence analysis. London: Academic Press.

Greenacre, M.J. 1988. 'Clustering the rows and columns of a contingency table', Journal of Classification, March, p39-51.

Grönroos, C. 1991. 'The marketing strategy continuum: a marketing concept for the 1990', Management Decision, Vol. 29, No. 1: 713.

Grönroos, C. 1994. 'From marketing mix to relationship marketing: toward a paradigm shift in marketing', Management Decision, Vol. 32, No. 2: 4-20.

Guseman, D.S. 1977. The perception of risk in consumer services - a comparison with consumer products. Unpublished DBA dissertation, University of Colorado.

Guseman, D.S. 1988. 'Risk perception and risk reduction in consumer services'. In Donnelly, J.H. \& George, W.R. (eds.). Marketing of services. Chicago: American Marketing Association, 200 204pp.

Hair, J.F., Anderson, R.E., Tatham, R.L. \& Black, W.C. 1992. Multivariate data analysis with readings. 3rd edition. New York: Macmillan Publishing Co. 
Hoffman, D.L. \& Franke, G.R. 1986. 'Correspondence analysis: graphical representation of categorical data in marketing research', Journal of Marketing Research, Vol. XXIII, August: 213227.

Jacoby, J. \& Kaplan, L. 1972. 'The components of perceived risk'. In Venkatesan, P. (ed.). Proceedings. Third Annual Convention of the Association for Consumer Research, 382-393pp.

Kaplan, L., Szybillo, G.L. \& Jacoby, J. 1974. 'Components of perceived risk in product purchase: a cross-validation', Journal of Ap. plied Psychology, Vol. 59, No. 3: 287-291.

Kellen, A. S. 1990. The evaluation of medical service quality by hospital inpatients. Unpublished MBA research report, Johannesburg: University of the Witwatersrand.

Lewis, W. 1976. An empirical investigation of the conceptual relationship between services and products in terms of perceived risk. Unpublished $\mathrm{Ph}$.D. Dissertation, University of Cincinnati.

Lutz, R.J \& Reilly, P.J. 1973. 'An exploration of the perceived social and performance risk on consumer information acquisition'. In Ward, S. \& Wright, P. (ed.). Advances in consumer research. Proceedings of the Fourth Annual Convention of the Association for Consumer Research, 393-405pp.
McCartby, E.J. 1960. Basic marketing. Homewood: Irwin.

Parasuraman, A., Zeithaml, V.A. \& Berry, L.L. 1986. SERVQUAL: a multiple-item scale for measuring consumer perceptions of service quality. Report No. 86-108, August. Cambridge: Marketing Science Institute.

Perry, M. \& Hamm, B.C. 1969. 'Canonical analysis of the relationship between socioeconomic risk and personal influence in purchase decisions', Journal of Marketing Research, Vol. 6, August: 351-354.

Roselius, E. 1971. 'Consumer rankings of risk reduction methods', Journal of Marketing, Vol. 35: 56-61.

Taylor, J.W. 1974. 'The role of risk in consumer behaviour', Journal of Marketing, Vol. 38: 54-60.

Venegas, H. 1990. Perceptual differences between goods and services in the office supply market. Unpublished MBA research report, Johannesburg: University of the Witwatersrand.

Zeithaml, V.A. 1981. 'How consumer evaluation processes differ between goods and services'. In Donnelly, J.H. \& George, W.R. (eds.). Marketing of services. Chicago: American Marketing Association, 186-190pp. 